Menoufia J. Soil Sci., Vol. 4 December (2019) : 219 - 236

\title{
RESPONSE OF TWO LEVELS WHEAT CULTIVARS TO COMPOST APPLICATION IN SALINE SOILS
}

\author{
Kh. A. H. Shaban, Ghada A. Abdel-Kader and Seham M. Abd El-Aziem \\ Soil, Water and Environment Research Institute, ARC, Giza, Egypt
}

Received: Jul. 21, 2019

Accepted: Sep. 28,2019

ABSTRACT: Tow field experiments were conducted on a saline clay soil in Village ElRowad in Sahl El-Hussinia, El-Sharkia, and Governorate. The location lies between latitude $32^{\circ} / 00$ to $32^{\circ} / 15, N$ and longitude $30^{\circ} / 50$ to $31^{\circ} / 15 \mathrm{E}$. For two successive winter seasons 2017/2018 and 2018/2019 cultivated with two wheat (Triticium aestivum cv.) cultivars, to study the effect of soil salinity levels and compost on some soil chemical properties growth and grain yields of both cultivars wheat (Masr1 and Sakha 93). In two seasons, each experiment was carried out in split plot design with four replicates.

Results obtained that, the decreases of soil salinity for soil treated with compost after wheat Sakha 93 harvest. The decrease of soil salinity in the soil cultivated by Sakh 93 was higher than that found in the soil cultivated by wheat Masr1 respectively. On the other hand, the soil $\mathrm{pH}$ values were decreased from 8.7 to 7.98 in first season and 8.02 to 7.90 in second season as a result of compost applications. Also, the soil contents of available the $N, P, K, F e, M n$ and $Z n$ available in soils were increases with decreasing soil salinity in both seasons as a result of compost application. Plant length (cm); spike length (cm); No. of tiller/plant; No. of leaves/plant and No. of spike /plant were decreases with increasing soil salinity level, where these decreases with the plants of Sakha 93 cultivar were higher than theses found with the plants of Masr 1 cultivar. The application of compost to the soil had a decreased effect on wheat yield and yield components i.e. weight of spike/plant (g), weight of grains/spikes (g), weight of 1000 grins (g), straw yield and grains yield (ton/fed). In addition compost applications resulted in an increase of wheat plants uptake of $\mathrm{N}, \mathrm{P}, \mathrm{K}, \mathrm{Fe}, \mathrm{Mn}$ and $\mathrm{Zn}$ where, the content of these nutrients in grains sakha 93 than Masr1 varieties wheat. The effect of saline soil different levels on wheat varieties quality i.e. Carbohydrate (\%), protein and chlorophyll ( $\mathrm{mg} \mathrm{g}^{-1} \mathrm{f}$.w.) were increased decrease of soil salinity especially sakha 93 with or without compost than Masr1 in both sessions while the proline ( $\left.\mathrm{mg} \mathrm{g}^{-1} . f . w\right)$, content in grains of wheat plants was increases with increasing soil salinity level without compost .

Recommended:

The obtained data concluded that, the application of compost led to improve soil salinity properties and increase of wheat cultivar Sakha 93 productivity and its quality compared by Masr1 cultivar under saline soil conditions.

Key words: Soil salinity, Compost, Wheat varieties and productivity and quality.

\section{INTRODUCTION}

Total salt affected area in the world about 955 million hectares out of which 0.9 million ha. in Egypt. The majority of salt-affected soils in Egypt are located in the northern-central part of the Nile Delta and on its eastern and western sides.
Fifty five percent of the cultivated lands of northern Delta region are, twenty percent of the southern Delta and middle Egypt region and twenty five percent of the Upper Egypt regions are salt-affected soils (FAO, 1995). Soil salinity is one of the most imperative abiotic stress and 
limiting factor, (Koyro, 2006). Increasing soil salinity levels led to decrease of plant height, spike length, No. of spike, 1000 grains weight and yield (straw + grain), (Niaz et al 2016). Salinity can reduce crop yield with a significant metabolic effort afforded to plant adaptation, growth maintenance and stress responses with a subsequent decrease in yield (Munns and Gilliham, 2015)

Compost application to salt-affected soil promotes flocculation of clay minerals, which is an essential condition for the aggregation of soil particles and play larger water stable aggregates, increasing poreses spaces which increase soil air circulation necessary for growth of plants and microorganisms, (Rasool et al., 2007). The use of composts led to enhances soil fertility and reduces environmental risk, improves soil texture, helps retain soil moisture, increase nutrients contents in the soil, stimulates biological activities, encourages vigorous plant rooting system, helps bind nutrients and prevents them from being leached out of the soil, (Chitravadivu et al., 2009). The soil $\mathrm{pH}$ and $\mathrm{EC}$ reduction and increases of $N, P$ and $K$ available in soil as affected by compost application compared with control, (Seddik et al., 2016).

Wheat (Triticum turgidum L.) contents carbohydrate $78.10 \%$, protein $14.70 \%$, fat $2.10 \%$, minerals $2.10 \%$ and considerable proportions of vitamin (thiamine and vitamin B), (Lantican et al . 2005).
Wheat is one of the most effectual and commercial means of reclaiming hundreds of thousands of hectares of saline lands in Egypt. (Kandil et al., 2012) indicated that for high wheat germination characters and seedling parameters under salinity stress by using wheat Sakha 93 and Sakha 94 Cultivars than Masr1 and Masr2 under salinity concentrations levels up to $14 \mathrm{dSm}^{-1}$. Wheat is one of the most effectual and commercial means of reclaiming hundreds of thousands of hectares of saline lands in Egypt, (Koyro, 2006).

Therefore the study was carried out the response to evaluation of two wheat varieties (Sakha 93 and Masr1) productivity and quality to compost application under different levels soil salinity .

\section{MATERIALS AND METHODS}

The study was conducted on three saline clay soil in village El-Rowad in Sahl El-Hussinia, The location lies between latitude $32^{\circ} / 00$ to $32^{\circ} / 15, \mathrm{~N}$ and longitude $30^{\circ} / 50$ to $31^{\circ} / 15 \mathrm{E}$. ElSharkia, Governorate for two successive winter seasons 2017/2018 and 2018/2019 cultivated with two wheat (Triticium aestivum cv.) of cultivars (Masr1 and Sakha 93) to study the changes in the soil chemical properties as a result of compost application as well as its productivity of wheat. The irrigation water resources were El-Salam Canal at ratio of (1:1) mixed of agriculture drainage water and Nile water, which have chemical properties listed in Table (1):

Table (1): Chemical analysis of El-Salam canal irrigation water .

\begin{tabular}{|c|c|c|c|c|c|c|c|c|}
\hline \multirow{2}{*}{$\mathrm{pH}$} & \multirow{2}{*}{$\mathrm{EC} \mathrm{(dSm-1)}$} & \multicolumn{2}{|c|}{$\mathrm{N}(\mathrm{mg} / \mathrm{L})$} & $\mathrm{P}$ & $\mathrm{K}$ & $\mathrm{Fe}$ & $\mathrm{Mn}$ & $\mathrm{Zn}$ \\
\cline { 3 - 7 } & & $\mathrm{NO}_{3}-\mathrm{N}$ & $\mathrm{NH}_{4}-\mathrm{N}$ & \multicolumn{5}{|c|}{$\mathrm{mg} / \mathrm{L}$} \\
\hline 7.98 & 1.58 & 21.94 & 12.30 & 5.90 & 13.74 & 3.88 & 1.46 & 1.10 \\
\hline
\end{tabular}


The initial physical and chemical properties of the cultivated soils were determined before planting according to the methods described by Cottenie et al (1982), Page et al (1982) and Kulte (1986) and the obtained data were recorded in Table (2).

The used compost analyzed was according to the standard methods described by Brunner and Wasmer (1978) and the results shown in Table (3).

\section{Field experiments:}

In two seasons, each experiment was carried out in split plot design with four replicates. The mean factor was soil salinity levels $(8.44,12.55$ and 16.20 $\mathrm{dS} / \mathrm{m}^{-1}$ ) includes two divisions and the sub plots the first division with compost and second division without compost. The two tested cultivars wheat (Masr1 and Sakha 93) which obtained from Crop
Institute Agriculture Research Center, Giza, Egypt. The area of each experimental unit plot was $5 \times 10 \mathrm{~m}$. Compost was added during soil preparation before wheat planting by 20 days at a rate of 5 ton/ fed.

Before cultivation the soils of the three salinity was subjected to some pretreatments processes as follows:- a) Leveling the soil surface by using lazar technique. b) Deep sub-soiling plough. c) Establishment of filed drains at a distance of $10 \mathrm{~m}$ between each of tow drains and a deep of $90 \mathrm{~cm}$ at drain beginning, where their drainage water flow towards the main collectors of $2 \mathrm{~m}$ in depth and d) establishment of an irrigation canal in the middle part of the experimental pilot unit. All tillage processes were carried out before sowing.

Table (2). Some initial physical and chemical properties of soil before planting.

\begin{tabular}{|c|c|c|c|c|c|c|c|c|c|}
\hline \multirow{3}{*}{$\begin{array}{c}\text { Soil } \\
\text { salinity } \\
\text { levels }\end{array}$} & \multirow{2}{*}{\multicolumn{5}{|c|}{ Particle size distribution (\%) }} & \multirow{3}{*}{ Texture } & \multirow{3}{*}{\multicolumn{2}{|c|}{ O.M (\%) }} & \multirow{3}{*}{$\begin{array}{c}\mathrm{CaCO}_{3} \\
(\%)\end{array}$} \\
\hline & & & & & & & & & \\
\hline & $\begin{array}{c}\text { Coarse } \\
\text { sand }\end{array}$ & Fine sand & Silt & \multicolumn{2}{|c|}{ Clay } & & & & \\
\hline S1 & 5.95 & 14.34 & 24.14 & \multicolumn{2}{|c|}{55.57} & Clay & \multicolumn{2}{|c|}{0.57} & 9.25 \\
\hline S2 & 7.53 & 17.74 & 20.89 & \multicolumn{2}{|c|}{54.14} & Clay & \multicolumn{2}{|c|}{0.55} & 11.75 \\
\hline \multirow[t]{3}{*}{ S3 } & 5.40 & 16.90 & 23.90 & 53.80 & & Clay & 0.5 & & 12.20 \\
\hline & \multirow{2}{*}{$\begin{array}{c}\text { pH } \\
(1: 2.5)\end{array}$} & \multirow{2}{*}{$\begin{array}{c}\text { EC } \\
\left(\mathrm{dSm} \mathrm{m}^{-1}\right) \\
\text { Soil peast }\end{array}$} & \multicolumn{4}{|c|}{ Soluble cations (meq/l) } & \multicolumn{3}{|c|}{ Soluble anions (meq/l) } \\
\hline & & & $\mathrm{Ca}^{++}$ & $\mathbf{M g}^{++}$ & $\mathrm{Na}^{+}$ & $\mathrm{K}^{+}$ & $\mathrm{HCO}_{3}{ }^{-}$ & $\mathrm{Cl}^{-}$ & $\mathrm{SO}_{4}^{--}$ \\
\hline s1 & 8.05 & 8.44 & 7.63 & 12.88 & 63.04 & 0.85 & 5.80 & 54.88 & 23.72 \\
\hline s2 & 8.12 & 12.55 & 15.63 & 22.85 & 86.23 & 0.79 & 7.88 & 70.25 & 47.37 \\
\hline S3 & 8.15 & 16.20 & 18.52 & 29.14 & 113.59 & \begin{tabular}{l|l}
9 & 0.75
\end{tabular} & 12.17 & 100.85 & \begin{tabular}{l|l}
5 & 48.98
\end{tabular} \\
\hline \multicolumn{5}{|c|}{ Available macronutrients $(\mathrm{mg} / \mathrm{kg})$} & \multicolumn{5}{|c|}{ Available micronutrients $(\mathrm{mg} / \mathrm{kg})$} \\
\hline & $\mathbf{N}$ & $\mathbf{P}$ & K & \multicolumn{2}{|c|}{$\mathrm{Fe}$} & & \multicolumn{2}{|l|}{ Mn } & Zn \\
\hline s1 & 38.46 & 4.86 & 185 & \multicolumn{2}{|c|}{6.33} & & \multicolumn{2}{|l|}{2.95} & 0.66 \\
\hline s2 & 35.89 & 3.52 & 173 & \multicolumn{2}{|c|}{5.77} & & \multicolumn{2}{|l|}{2.48} & 0.62 \\
\hline S3 & 33.86 & 3.19 & 170 & \multicolumn{2}{|c|}{4.88} & & \multicolumn{2}{|l|}{2.40} & 0.59 \\
\hline
\end{tabular}


Kh. A. H. Shaban, et al.,

Table (3): Chemical analysis of compost.

\begin{tabular}{|c|c|c|c|c|c|c|c|c|c|c|c|}
\hline \multirow{2}{*}{$\begin{array}{c}\text { Moisture } \\
\text { content } \%\end{array}$} & \multirow{2}{*}{$\begin{array}{c}E C \\
d^{-1} m^{-1} \\
(1: 10)\end{array}$} & pH & C & $\begin{array}{l}\mathrm{C} / \mathrm{N} \\
\text { ratio }\end{array}$ & O.M & $\mathbf{N}$ & $\mathbf{P}$ & K & $\mathrm{Fe}$ & Mn & $\mathrm{Zn}$ \\
\hline & & $(1: 2.5)$ & \multicolumn{6}{|c|}{ (\%) } & \multicolumn{3}{|c|}{$\left(\mathrm{mgkg}^{-1}\right)$} \\
\hline 27 & 3.55 & 7.48 & 33.20 & 15.66 & 41.00 & 2.12 & 0.70 & 2.22 & 231.00 & 112.00 & 98.00 \\
\hline
\end{tabular}

Super phosphate $\left(15.5 \% \mathrm{P}_{2} \mathrm{O}_{5}\right)$ was applied at rate $200 \mathrm{~kg} / \mathrm{fed}$ as soil application before planting. Urea (46\% N) was applied as $\mathrm{N}$ fertilizer at rate $100 \mathrm{~kg}$ $\mathrm{N} / \mathrm{fed}$ at three period after 30,45 and 65 days of sowing. Potassium sulphate (48 $\% \mathrm{~K}_{2} \mathrm{O}$ ) was applied at rate $75 \mathrm{~kg} / \mathrm{fed}$ at 30 and $\mathbf{4 5}$ days after planting.

The grains of wheat plants were sowing in the $15^{\text {th }}$ of November 2017 and 2018 respectively. Six plants were taken randomly from each replicate after 75 days of sowing and prepared for some vegetative growth parameters and some physiological determination. Total proline content was estimated according to the methods described by Bates et al (1973). Photosynthetic (total chlorophyll) was estimated in fresh leave as described by Witham et al (1971). Then grains were seprated from straw in (20 May 2018 and 2019) respectively. Total carbohydrates were determined in dry seeds using the method described by Dubois et al., (1956).

At harvesting stage ten plants of each replicate were taken and subjected to some growth parameters, Plant length (cm), Spike length $(\mathrm{cm})$, No. tiller/plant, No. of leaves/plant, weight of spike/plant (g), weight of grains/spikes (g), weight of 1000 grains $(\mathrm{g})$, weight of grains yield (ton/fed) and weight straw yield (ton/fed).

After crop harvesting soil samples at depth of $(0-30 \mathrm{~cm})$ were collected separated from each plots. The soil samples were air-dried, ground to pass through a $2 \mathrm{~mm}$ sieve, and analyses for some soil properties i.e. soil $\mathrm{pH}$, soil salinity $\left(E C \mathrm{dSm}^{-1}\right)$ and available $(\mathrm{N}, \mathrm{P}, \mathrm{K}$,
Fe, Mn and $\mathrm{Zn}$ according to Cotton et al (1982) and Page et al (1982).

Plant samples were air- dried oven dried at $70 \mathrm{C}^{\circ}$ ground and kept for chemical analysis. A $0.4 \mathrm{~g}$ dry ground grain and straw were wet-dgested using mixture of concentration sulphuric and percholoric acids and different analysis were done according to Ryan et al (1996).

Statistical analysis was assigned using MSTAT-C developed by Russell (1994).

\section{RESULTS AND DISCUSSION} Soil salinity: (EC (dSm-1).

The studied three saline soils have a EC values greater than $4 \mathrm{dS} / \mathrm{m}$, and soil $\mathrm{pH}$ less than 8.3. The three levels of soil salinity ranging from $16.20,12.55$ and $8.12 \mathrm{dSm}^{-1}$ classified as very high salinity before planting, to 9.70 to 4.10 for soil treated with compost in both seasons and 10.75 and $5.10 \mathrm{dSm}^{-1}$ for soil untreated compost in both seasons classified as medium to very high soil salinity. These decreases may be resulted from the development and increase of soil permeability in soil treated with compost. The decrease of soil salinity different levels and with or untreated compost was no significant in both seasons. There decreases were significant in the soil treated with compost. The obtained decreases were resulted from leaching soluble salts with irrigation water and it's absorbed by grown plant, (Hammad et al., 2010). The relative decreases of soil salinity were $31.87,31.47$ and $40.12 \%$ for soil treated with compost with Sakha 93 and were $37.91,41.35$ and $47.22 \%$ for soil treated 
with compost with Masr1 in S1, S2 and S3, respectively compared with different soil salinity levels before planting in first season. In addition, these relative decrease in the first season were 18.48 , 24.30 and $32.84 \%$ for soil without compost with Sakha 93 and were values 24.05, 30.92 and $41.98 \%$ with Masr1 compared with soils salinity levels before planting. Concerning the relative decreases of EC values were 49.64, 48.77 and $48.77 \%$ of soil untreated with compost for Sakha 93 and were 51.42, 52.35 and $51.36 \%$ for soil treated with compost for Masr1 with soils salinity different levels before wheat planting in second season. Also, the relative decreases of soil salinity values were $33.65, \quad 36.73$ and $45.06 \%$ for soil untreated compost after Sakha 93 and were $39.57,52.19$ and $48.40 \%$ for soil untreated compost with Masr1 compared soils salinity levels before planting in second season. These findings are in agreement with those reported by Tandon (2000) who indicated that physical properties (hydraulic conductivity, bulk density and total porosity) of salt affected soil greatly improved when compost is applied. The decomposition of compost releases acids forming compounds and active microorganisms, which react with the soluble salts already present in soil either to convert them into soluble salts or at least increase their solubility, (Nasef et al., 2009) . Abo-Soleman et al. (2001), found that the highest rates of salt leaching were achieved with Nile water if it used continuously $47.15 \%$ through season. These results may be due to the applied compost led to activity of microorganism to reduce salinity and simultaneously improve characterization of soil structure (increasing drainable porosity and aggregate stability) and consequently enhanced leaching process through growth of two varieties of wheat in both seasons. Mariangela and Francesco
(2015) reported that the application of compost to saline soil led to decrease bulk density and soil EC.

\section{Soil pH.}

Under different saline soils treated with or without compost as well as with the two wheat varieties there are variation with in soil $\mathrm{pH}$ as shown in Table (4). Applied compost decreased soil $\mathrm{pH}$ in both seasons compared without compost applications. The soils with all experimental treatments characterized by slightly to moderately alkaline conditions, where $\mathrm{pH}$ values is around 8.7 to 7.98 in the first season and 8.02 to 7.90 in the second season for soil treated with compost. This finding is expected due to the application of compost led to increases microorganism and biological activities by organic acid produced. These results are in agreement by El-Mazz et al. (2014) suggested that the application of compost led to decrease soil $\mathrm{pH}$, reflected to the activity of microorganism and organic acid produced.

\section{Available macronutrients in soils study.}

Data presented in Table (4) show that the with different soil salinity levels as affected by compost application, the soil content of available macronutrients were increased and decreased with the increase of soil salinity levels, where this decrease was non significant. these findings were observed in the tow growth seasons as well as with the two cultivars of wheat plants for both seasons the content of available $N$ and $P$, while the $K$ content in soil was significant decreased with increase soil salinity levels. The interaction between soil salinity levels and compost on the content of available $\mathbf{N}$ content in soil treated with compost was significant in first season while no significant in second season. Also, the interaction between soil salinity and 
Kh. A. H. Shaban, et al.,

compost on the content available $P$ in soil un-treated and with compost was significant increases affected in first and second seasons. As well as, the interaction between soil salinity and compost on available $\mathrm{K}$ content in soil was no significant in first season, while the significant in second season as affected with or without compost. These results are in agreement by Wang et al (2016) who, found that the application of compost was increase of available $\mathbf{N}$ and $K$ content in soil, while the available $P$ in soil was not affected after wheat harvest. It might be due to the direct addition of $\mathrm{N}$ from the decomposition of organic matter (compost) and mineralization of organically bound nitrogen. Also, the residual effect of organic mater was higher in increasing available $K$ than control. The increase in $K$ availability as the residual effect of organic mater was due to higher microbial activities in soil which influenced the release of nonexchangeable or fixed $-\mathrm{K}$ forms into available forms Seddik et al (2016).

Table (4). Soil pH, EC and its available macronutrients content $(\mathrm{mg} / \mathrm{kg})$ after wheat harvest.

\begin{tabular}{|c|c|c|c|c|c|c|c|c|c|c|c|}
\hline \multirow{3}{*}{$\begin{array}{c}\text { Varity } \\
\text { of } \\
\text { wheat }\end{array}$} & \multirow{3}{*}{$\begin{array}{c}\text { Levels of } \\
\text { soil } \\
\text { salinity }\end{array}$} & \multicolumn{2}{|c|}{$\begin{array}{c}\mathrm{pH} \\
(1: 2.5)\end{array}$} & \multicolumn{2}{|c|}{$\begin{array}{c}E C \\
\left(\mathrm{dSm}^{-1}\right)\end{array}$} & \multicolumn{2}{|c|}{$\begin{array}{c}\mathbf{N} \\
\left(\mathbf{m g k g}^{-1}\right)\end{array}$} & \multicolumn{2}{|c|}{$\begin{array}{c}\mathbf{P} \\
\left(\mathrm{mgkg}^{-1}\right)\end{array}$} & \multicolumn{2}{|c|}{$\begin{array}{c}\mathrm{K} \\
\left(\mathrm{mgkg}^{-1}\right)\end{array}$} \\
\hline & & \multicolumn{2}{|c|}{ Compost } & \multicolumn{2}{|c|}{ Compost } & \multicolumn{2}{|c|}{ Compost } & \multicolumn{2}{|c|}{ Compost } & \multicolumn{2}{|c|}{ Compost } \\
\hline & & With & Withou & With & Without & With & Without & With & Without & With & Without \\
\hline \multicolumn{12}{|c|}{ First season $2017 / 2018$} \\
\hline \multirow{3}{*}{$\begin{array}{c}\text { Sakha } \\
93\end{array}$} & s1 & 8.01 & 8.04 & 5.75 & 6.88 & 46.86 & 43.52 & 5.12 & 4.95 & 198.00 & 190.00 \\
\hline & S2 & 8.06 & 8.09 & 8.60 & 9.50 & 42.52 & 40.89 & 4.22 & 3.85 & 184.00 & 178.00 \\
\hline & S3 & 8.07 & 8.12 & 9.70 & 10.88 & 41.95 & 40.10 & 3.85 & 3.70 & 180.00 & 176.00 \\
\hline \multirow{3}{*}{ Masr 1} & S1 & 7.98 & 8.03 & 5.24 & 6.41 & 47.69 & 44.10 & 5.45 & 5.10 & 205.00 & 195.00 \\
\hline & s2 & 8.03 & 8.06 & 7.36 & 8.67 & 44.10 & 41.23 & 4.88 & 3.99 & 195.00 & 184.00 \\
\hline & S3 & 8.04 & 8.09 & 8.55 & 9.40 & 43.18 & 40.95 & 4.15 & 3.85 & 189.00 & 180.00 \\
\hline \multicolumn{2}{|c|}{ LSD. 0.05 salinity } & ---- & ---- & ns & ns & ns & ns & ns & ns & ns & 2.15 \\
\hline \multicolumn{2}{|c|}{$\begin{array}{l}\text { LSD. } 0.05 \\
\text { compost }\end{array}$} & ---- & --- & ns & ns & ns & ns & ns & 1.22 & ns & ns \\
\hline \multicolumn{2}{|c|}{ Interaction } & --- & ---- & $* *$ & * & ** & ns & $* * *$ & $* * *$ & ns & $* * *$ \\
\hline \multicolumn{12}{|c|}{ Second season 2018/ 2019} \\
\hline \multirow{3}{*}{$\begin{array}{c}\text { Sakha } \\
93\end{array}$} & S1 & 7.94 & 8.00 & 4.25 & 5.60 & 49.34 & 45.85 & 5.60 & 5.14 & 203.00 & 198.00 \\
\hline & S2 & 8.01 & 8.04 & 6.49 & 7.94 & 46.17 & 42.65 & 4.88 & 4.25 & 195.00 & 188.00 \\
\hline & S3 & 8.02 & 8.05 & 8.30 & 8.90 & 44.20 & 41.55 & 4.35 & 3.98 & 188.00 & 182.00 \\
\hline \multirow{3}{*}{ Masr 1} & S1 & 7.90 & 7.99 & 4.10 & 5.10 & 50.12 & 47.39 & 5.89 & 5.22 & 208.00 & 202.00 \\
\hline & S2 & 7.96 & 8.02 & 5.98 & 6.00 & 47.69 & 44.40 & 5.22 & 4.75 & 200.00 & 195.00 \\
\hline & S3 & 7.98 & 8.03 & 7.88 & 8.36 & 45.88 & 43.98 & 4.85 & 4.35 & 194.00 & 190.00 \\
\hline \multicolumn{2}{|c|}{ LSD. 0.05 salinity } & --- & --- & ns & ns & ns & ns & ns & ns & ns & ns \\
\hline \multicolumn{2}{|c|}{$\begin{array}{l}\text { LSD. } 0.05 \\
\text { compost }\end{array}$} & ---- & --- & ns & ns & ns & ns & ns & ns & 1.05 & ns \\
\hline \multicolumn{2}{|c|}{ Interaction } & ---- & ----- & $* * *$ & $\star * * *$ & ns & ** & * & * & $* * *$ & $* * *$ \\
\hline
\end{tabular}


Response of two levels wheat cultivars to compost application in saline ......

Available micronutrients.

Presented data in Table (5) show that the content of some available micronutrients i.e Fe, Mn and $\mathrm{Zn}\left(\mathrm{mgkg}^{-1}\right)$ in the studied saline soils and with or untreated compost. Generally, data show that, the available Fe Mn and $\mathrm{Zn}$ content in soil were caused markedly increase with decrease of soil salinity treated with compost compared without compost. Increasing the soil content available of $\mathrm{Fe}, \mathrm{Mn}$ and $\mathrm{Zn}$ due to the application of compost might be a result of its decomposition products (organic acids), which increases the nutrients availability in the soil. The effect of different soil salinity levels with and without compost on these content of the soil content of available micronutrients after wheat harvest was no significant for $\mathrm{Fe}$ and $\mathrm{Zn}$ in first season while its was significant was $\mathrm{Mn}$ in first and second season. As well as, content of available of $\mathrm{Fe}$ in soil was significant decrease for soil untreated with compost and was significant with Mn content in soil treated with compost, while the $\mathrm{Zn}$ content in soil was no significant affected in soil treated with compost in second season. The interaction between soil salinity levels and compost on the content of available $\mathrm{Fe}$ and $\mathrm{Zn}$ were significant increases with decreasing soil salinity in all soil treated with compost, while the content available Mn was significant for soil treated with compost in second season. Thus it could be concluded that the more pronounced increase in the available $\mathrm{Fe}, \mathrm{Mn}$ and $\mathrm{Zn}$ contents in saline soils as a result of increasing the applied compost may be attributed to improve soil $\mathrm{pH}$. These results are in agreement by Soheil et al. (2012) reported that the application of compost increased significantly of available $\mathrm{Fe}, \mathrm{Mn}$ and $\mathrm{Zn}$ in the saline soil.

Table (5). Soil content $(\mathrm{mg} / \mathrm{kg})$ available of micronutrients after wheat harvest.

\begin{tabular}{|c|c|c|c|c|c|c|c|}
\hline \multirow{3}{*}{ Varity of wheat } & \multirow{3}{*}{$\begin{array}{l}\text { Levels of } \\
\text { soil } \\
\text { salinity }\end{array}$} & \multirow{2}{*}{\multicolumn{2}{|c|}{$\begin{array}{c}\begin{array}{c}\mathrm{Fe} \\
\left(\mathrm{mgkg}^{-1}\right)\end{array} \\
\text { Compost }\end{array}$}} & \multirow{2}{*}{\multicolumn{2}{|c|}{$\begin{array}{c}\begin{array}{c}\text { Mn } \\
\left(\mathbf{m g k g}^{-1}\right)\end{array} \\
\text { Compost }\end{array}$}} & \multirow{2}{*}{\multicolumn{2}{|c|}{$\begin{array}{c}\begin{array}{c}\mathrm{Zn} \\
\left(\mathrm{mgkg}^{-1}\right)\end{array} \\
\text { Compost }\end{array}$}} \\
\hline & & & & & & & \\
\hline & & With & Without & With & Without & With & Without \\
\hline & & \multicolumn{6}{|c|}{ First season $2017 / 2018$} \\
\hline \multirow{3}{*}{ Sakha 93} & S1 & 6.88 & 6.55 & 3.15 & 2.99 & 0.75 & 0.71 \\
\hline & $\mathbf{S 2}$ & 5.90 & 5.80 & 2.89 & 2.66 & 0.68 & 0.64 \\
\hline & S3 & 5.12 & 4.92 & 2.70 & 2.51 & 0.60 & 0.57 \\
\hline \multirow{3}{*}{ Masr 1} & S1 & 7.22 & 6.87 & 3.55 & 3.06 & 0.79 & 0.75 \\
\hline & S2 & 6.18 & 5.99 & 2.96 & 2.79 & 0.71 & 0.66 \\
\hline & S3 & 5.37 & 5.30 & 2.84 & 2.65 & 0.68 & 0.60 \\
\hline \multicolumn{2}{|c|}{ LSD.0.05 salinity } & ns & ns & 0.060 & ns & ns & ns \\
\hline \multicolumn{2}{|c|}{ LSD. 0.05 compost } & ns & ns & 0.053 & ns & ns & ns \\
\hline \multicolumn{2}{|c|}{ Interaction } & $* * *$ & $* *$ & $* * *$ & ns & $* * *$ & ** \\
\hline & & \multicolumn{6}{|c|}{ Second season 2018/ 2019} \\
\hline \multirow{3}{*}{ Sakha 93} & S1 & 7.85 & 6.89 & 3.78 & 3.12 & 0.80 & 0.74 \\
\hline & S2 & 6.55 & 6.05 & 2.88 & 2.74 & 0.75 & 0.70 \\
\hline & S3 & 5.88 & 5.35 & 2.79 & 2.69 & 0.70 & 0.65 \\
\hline \multirow{3}{*}{ Masr 1} & S1 & 7.96 & 6.99 & 3.85 & 3.26 & 0.85 & 0.77 \\
\hline & S2 & 6.85 & 6.15 & 2.95 & 2.79 & 0.78 & 0.69 \\
\hline & S3 & 6.45 & 5.85 & 2.89 & 2.72 & 0.74 & 0.67 \\
\hline \multicolumn{2}{|c|}{ LSD. 0.05 salinity } & ns & 0.051 & 0.007 & ns & ns & ns \\
\hline \multicolumn{2}{|c|}{ LSD. 0.05 compost } & ns & 0.062 & 0.019 & ns & ns & ns \\
\hline \multicolumn{2}{|c|}{ Interaction } & *** & *** & $* * *$ & ns & *** & $* *$ \\
\hline
\end{tabular}


Kh. A. H. Shaban, et al.,

El-Shinnawi et al (2009) and Hammad et al (2010) they found that the increase of available micronutrients in soil may be resulted from the effect of farming processes and added compost. Also, the compost may play a vital role for increasing nutrients availability through the processes of chelating, biochemical processes and production of several organic acids during decomposition of compost. Compost was added to reclamation saline soils by improving physical, chemical and biological properties, Abd Eladl et al., (2010).

Vegetative growth parameters of wheat varieties.

Data presented in Table (6) show a decreases in plant length $(\mathrm{cm})$; spike length $(\mathrm{cm})$; No. of tiller/plant; No. of leaves/plant and No. of spke /plant with increasing soil salinity level either with and without compost where these decreases were higher in the plants untreated with compost. At the same salinity levels of soil un- and treated with compost estimated vegetative growth parameters for Sakha 93 cultivar were higher than these for Misr 1. Theses results are in agreement by El-Hamahmy et al., (2014) who, indicate that, application compost led to an enhancement of soil aggregation process, subsequently soil penetrability resistance decrease and reduce the effect of salt stress and promotes the parameters of plant growth that reflected the healthy state of plants where low level of salinity increased cell wall synthesis, cell enlargement and photosynthetic activities increase the amount of total chlorophyll in plants.

Table (6). Vegetative growth parameters of wheat plants affected the studied.

\begin{tabular}{|c|c|c|c|c|c|c|c|c|c|c|c|}
\hline \multirow{3}{*}{$\begin{array}{c}\text { Varity } \\
\text { of } \\
\text { wheat }\end{array}$} & \multirow{3}{*}{$\begin{array}{c}\text { Levels of } \\
\text { soil } \\
\text { salinity }\end{array}$} & \multirow{2}{*}{\multicolumn{2}{|c|}{$\begin{array}{c}\text { Plant length } \\
\text { (cm) } \\
\text { Compost }\end{array}$}} & \multirow{2}{*}{\multicolumn{2}{|c|}{$\begin{array}{c}\text { Spike length } \\
\text { (cm) } \\
\text { Compost }\end{array}$}} & \multirow{2}{*}{\multicolumn{2}{|c|}{$\begin{array}{c}\text { No. } \\
\text { tiller/plant } \\
\text { Compost }\end{array}$}} & \multirow{2}{*}{\multicolumn{2}{|c|}{\begin{tabular}{|c|}
$\begin{array}{c}\text { No. of leaves } \\
\text { /plant }\end{array}$ \\
Compost
\end{tabular}}} & \multicolumn{2}{|c|}{$\begin{array}{c}\text { No. of } \\
\text { spike/plant }\end{array}$} \\
\hline & & & & & & & & & & Co & npost \\
\hline & & \multirow[t]{2}{*}{ With } & \multirow[t]{2}{*}{ Without } & \multicolumn{2}{|c|}{ With Without } & \multicolumn{2}{|c|}{ With Without } & \multicolumn{2}{|c|}{\begin{tabular}{|l|l|} 
With & Without \\
\end{tabular}} & \multicolumn{2}{|c|}{\begin{tabular}{|l|} 
With Without \\
\end{tabular}} \\
\hline \multicolumn{10}{|c|}{ First season $2017 / 2018$} & & \\
\hline \multirow{3}{*}{$\begin{array}{c}\text { Sakha } \\
93\end{array}$} & S1 & 105.00 & 94.00 & 11.45 & 10.26 & 4.95 & 3.88 & 20.54 & 18.44 & 4.77 & 3.88 \\
\hline & $\mathbf{S 2}$ & 99.00 & 81.00 & 10.29 & 9.67 & 4.20 & 3.50 & 18.69 & 16.28 & 4.12 & 3.45 \\
\hline & S3 & 84.00 & 75.90 & 9.22 & 8.53 & 3.98 & 3.44 & 15.44 & 14.96 & 3.87 & 3.10 \\
\hline \multirow{3}{*}{ Masr 1} & s1 & 103.00 & 90.00 & 10.48 & 8.95 & 4.38 & 3.76 & 18.34 & 17.55 & 4.26 & 3.40 \\
\hline & S2 & 87.00 & 79.00 & 8.10 & 7.42 & 4.10 & 3.23 & 16.84 & 15.83 & 3.75 & 3.22 \\
\hline & S3 & 81.00 & 70.00 & 6.88 & 6.49 & 3.65 & 3.10 & 14.96 & 12.63 & 2.89 & 2.95 \\
\hline \multicolumn{2}{|c|}{ LSD.0.05 salinity } & 4.55 & 6.24 & m & 0.85 & ns & 1.35 & ns & 1.73 & ns & ns \\
\hline \multicolumn{2}{|c|}{$\begin{array}{l}\text { LSD. } 0.05 \\
\text { compost }\end{array}$} & ns & ns & ns & ns & ns & 1.22 & ns & ns & ns & ns \\
\hline \multicolumn{2}{|c|}{ Interaction } & ** & *** & ns & ns & ** & 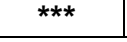 & ns & $n c$ & ns & s \\
\hline \multicolumn{12}{|c|}{ Second season 2018/2019 } \\
\hline \multirow{3}{*}{$\begin{array}{c}\text { Sakha } \\
93\end{array}$} & $\mathbf{S 1}$ & 109. & 89.00 & 12.55 & 11.90 & 5.10 & 4.80 & 21 & & 5.22 & 4 \\
\hline & $\mathbf{S 2}$ & 103.00 & 78.00 & 10.75 & 9.85 & 4.89 & 4.50 & 19.16 & 17.20 & 5.12 & 3.85 \\
\hline & S3 & 92.00 & 72.00 & 8.4 & 7.1 & 4.65 & 4.10 & 16.77 & 15.30 & 4.00 & 3.21 \\
\hline \multirow{3}{*}{ Masr 1} & S1 & 105.00 & 85.00 & 11.56 & 9.65 & 4.70 & 4.56 & 20.56 & 18.22 & 4.98 & 3.86 \\
\hline & $\mathbf{S 2}$ & 96.00 & 75.00 & 9.50 & 8.44 & 4.50 & 4.33 & 17.94 & 16.86 & 4.21 & 3.11 \\
\hline & S3 & 88.00 & 68.00 & 7.79 & 6.50 & 4.22 & 4.00 & 15.00 & 14.65 & 3.29 & 3.00 \\
\hline \multicolumn{2}{|c|}{ LSD.0.05 salinity } & 2.56 & 2.99 & ns & 2.30 & ns & ns & ns & ns & ns & ns \\
\hline \multicolumn{2}{|c|}{$\begin{array}{l}\text { LSD. } 0.05 \\
\text { compost }\end{array}$} & ns & ns & n & ns & ns & $\mathbf{n}$ & ns & ns & ns & 0 \\
\hline \multicolumn{2}{|c|}{ Interaction } & ** & *** & *** & *** & ns & ns & ns & ns & * & ns \\
\hline
\end{tabular}


The effect of soil salinity levels on plant length $(\mathrm{cm})$ was significant especially at high salinity level findings were observed with other parameters under study in both seasons. In exception the No. of spike /plant was no significant affected by soil salinity treated with or without compost in both seasons. On the other hand, the effect of compost applied on plant length $(\mathrm{cm})$; spike length (g) and No. of leaves /plant of wheat varieties were no significant increases in both seasons, while the No. of spike was significant increases with decrease saline soil levels in second season. These results are same by Ghumlam et al., (2013) and Niaz et al., (2016) found that the increasing of soil salinity significantly decreased of plant height, spike length, No. of spike/plant and No. of grain /plant respectively. Among the cultivars under investigation Sakha 93 cultivar appeared to be more tolerant to salinity compared with Maser1 cultivar. These results might due to genetic variation exist among wheat cultivars in both seasons of early growth rate under salt stress condition.

Yield and yield components of wheat cultivars.

Effect of different soil salinity levels and compost on yield of wheat was presented in Table (7). This data show that application of compost to the soil had a decreased effect of soil salinity, where its application resulted in a significant increased on wheat yield and yield components i.e. weight of spike/plant (g), weight of grains/spikes (g), weight of 1000 grins (g), straw yield and grains yield (ton/fed) these increments in yield may be due to the positive effect of added compost on soil properties and fertility. The decreases effect of soil salinity levels on weight of spike /plant (g) was significant with and without compost application, while the decreases in weight of 1000 grains (g) was significant, where these decreases effects were decreased with compost applications in both seasons.

Muzafar et al (2018) suggested that, the soil salinity affects the plants photosynthetic activity that results in low yield production. Reduced rate of photosynthesis in plants is one of the main causes behind decreased productivity. It cloud be that, the increase of wheat yield (straw and grain) ton/fed under soil salinity by using wheat cultivar Sakha 93 as affected with or without compost than Masr 1.

\section{Macronutrients concentration and} uptake in grains of wheat cultivation .

Results in Table (8) indicated that an increase effect of compost on $N, P$ and $K$ concentration and uptake (kg/fed) in wheat cultivars compared without compost. The in chanced effect of compost on plants grown in soil salinity increased the uptake of $N, P$ and $K$ in wheat cultivation plant due to the beneficial effect of compost for improving the nutritional status. The beast importance of role of compost was improving soil properties and increasing uptake of $N, P$ and $K$ of grains wheat in first season. The concentration of $N$ in grains of wheat cultivation in second season was no significant in soil treated with compost or without, while the $\mathrm{N}$ uptake was significant for soil treated with compost or without. The $\mathbf{P}$ concentration in grains wheat cultivars was increased significant by affected with compost in first seasons, while no significant in second season. The uptake of $P$ in grains wheat variety was no significant as affected with compost or without in first season, while no 
Kh. A. H. Shaban, et al.,

significant for soil with compost in second season. Addition, the concentration of $K$ in grains of wheat varieties was no significant with compost by increased the in first season, while, significant in second season. The uptake of $K$ in grains of wheat varieties was significant affected with compost in first season, while no significant.

These results are in agreement by ElQuesni et al (2010) found that the compost application on $\mathrm{N}, \mathrm{P}$ and $\mathrm{K}$ concentration and uptake increased at low level of salinity. Babbu et al (2015) indicated that the application of compost on $\mathrm{N}, \mathrm{P}$ and $\mathrm{K}$ concentrations and uptake in wheat and maize was significant increases. This result reflected to applied compost led to improved nutrient uptake of $\mathrm{N}, \mathrm{P}$ and $\mathrm{K}$ significantly compared to no treat.

Table (7). Yield component of wheat plants affected with soil salinity and compost applications.

\begin{tabular}{|c|c|c|c|c|c|c|c|c|c|c|c|}
\hline \multirow{3}{*}{$\begin{array}{c}\text { Varity } \\
\text { of } \\
\text { wheat }\end{array}$} & \multirow{3}{*}{$\begin{array}{l}\text { Levels of } \\
\text { soil } \\
\text { salinity }\end{array}$} & \multirow{2}{*}{\multicolumn{2}{|c|}{$\begin{array}{c}\begin{array}{c}\text { Weight of } \\
\text { spike/plant } \\
\text { (g) }\end{array} \\
\text { Compost }\end{array}$}} & \multirow{2}{*}{\multicolumn{2}{|c|}{$\begin{array}{c}\begin{array}{c}\text { Weight of } \\
\text { grains/spikes } \\
(\mathbf{g})\end{array} \\
\text { Compost }\end{array}$}} & \multirow{2}{*}{\multicolumn{2}{|c|}{$\begin{array}{c}\begin{array}{c}\text { Weight of } \\
1000 \text { grains } \\
\text { (g) }\end{array} \\
\text { Compost }\end{array}$}} & \multirow{2}{*}{\multicolumn{2}{|c|}{\begin{tabular}{|c|}
$\begin{array}{c}\text { Weight of } \\
\text { grains yield } \\
\text { (ton/fed) }\end{array}$ \\
Compost \\
\end{tabular}}} & \multirow{2}{*}{\multicolumn{2}{|c|}{$\begin{array}{c}\begin{array}{c}\text { Weight of } \\
\text { straw yield } \\
\text { (ton/fed) }\end{array} \\
\text { Compost }\end{array}$}} \\
\hline & & & & & & & & & & & \\
\hline & & With & Without & With & Without & With & Without & With & Without & With & Without \\
\hline \multicolumn{12}{|c|}{ First season $2017 / 2018$} \\
\hline \multirow{3}{*}{$\begin{array}{c}\text { Sakha } \\
93\end{array}$} & S1 & 9.75 & 7.35 & 4.50 & 3.90 & 55.87 & 42.90 & 3.19 & 2.45 & 4.80 & 4.20 \\
\hline & S2 & 8.60 & 7.12 & 4.25 & 3.54 & 48.60 & 39.85 & 2.70 & 2.19 & 4.20 & 3.95 \\
\hline & S3 & 8.45 & 6.65 & 3.88 & 3.21 & 40.95 & 39.00 & 2.59 & 2.00 & 3.85 & 3.50 \\
\hline \multirow{3}{*}{ Masr 1} & S1 & 9.22 & 7.15 & 4.45 & 3.85 & 50.85 & 40.85 & 2.80 & 2.31 & 4.50 & 4.19 \\
\hline & S2 & 8.40 & 6.88 & 4.11 & 3.35 & 46.97 & 39.30 & 2.60 & 2.24 & 4.35 & 3.83 \\
\hline & S3 & 7.85 & 6.20 & 3.75 & 3.15 & 39.55 & 38.43 & 2.30 & 1.86 & 3.50 & 3.20 \\
\hline \multicolumn{2}{|c|}{ LSD.0.05 salinity } & ns & 0.40 & ns & ns & 5.81 & ns & ns & ns & ns & ns \\
\hline \multicolumn{2}{|c|}{$\begin{array}{l}\text { LSD. } 0.05 \\
\text { compost }\end{array}$} & ns & ns & ns & ns & ns & ns & ns & ns & ns & 1.12 \\
\hline \multicolumn{2}{|c|}{ Interaction } & ns & ns & * & ns & $* *$ & ns & ns & ns & ns & ** \\
\hline \multicolumn{12}{|c|}{ Second season 2018/ 2019} \\
\hline \multirow{3}{*}{$\begin{array}{c}\text { Sakha } \\
93\end{array}$} & S1 & 10.93 & 7.55 & 4.75 & 4.12 & 59.73 & 44.86 & 3.35 & 2.59 & 4.85 & 4.50 \\
\hline & S2 & 9.88 & 7.30 & 4.62 & 4.00 & 54.85 & 41.90 & 2.85 & 2.44 & 4.50 & 4.32 \\
\hline & S3 & 8.90 & 7.04 & 4.45 & 3.88 & 43.00 & 40.44 & 2.72 & 2.15 & 4.20 & 3.85 \\
\hline \multirow{3}{*}{ Masr 1} & S1 & 9.84 & 7.42 & 4.72 & 4.07 & 57.40 & 43.50 & 3.20 & 2.45 & 4.75 & 4.38 \\
\hline & s2 & 9.64 & 7.21 & 4.40 & 3.77 & 50.75 & 40.88 & 2.94 & 2.33 & 4.50 & 4.12 \\
\hline & S3 & 8.29 & 6.44 & 4.00 & 3.29 & 42.95 & 40.22 & 2.65 & 1.95 & 4.10 & 4.05 \\
\hline \multicolumn{2}{|c|}{ LSD.0.05 salinity } & ns & ns & ns & ns & 3.37 & ns & ns & ns & ns & ns \\
\hline \multicolumn{2}{|c|}{$\begin{array}{l}\text { LSD. } 0.05 \\
\text { compost }\end{array}$} & ns & ns & ns & ns & ns & ns & ns & ns & ns & 0.09 \\
\hline \multicolumn{2}{|c|}{ Interaction } & ** & ns & ns & ns & $\star * \star$ & ns & ns & ns & ns & ** \\
\hline
\end{tabular}


Response of two levels wheat cultivars to compost application in saline .....

Table (8). Macronutrients concentration and uptake in grains of wheat crop.

\begin{tabular}{|c|c|c|c|c|c|c|c|c|c|c|c|c|c|}
\hline \multirow{3}{*}{$\begin{array}{l}\text { Varity } \\
\text { of } \\
\text { wheat }\end{array}$} & \multirow{3}{*}{$\begin{array}{c}\text { Levels } \\
\text { of soil } \\
\text { salinity }\end{array}$} & \multicolumn{2}{|c|}{$\begin{array}{c}N \\
(\%)\end{array}$} & \multicolumn{2}{|c|}{$\begin{array}{c}\text { Uptake of } \\
\mathrm{N} \\
\text { (kg/fed) }\end{array}$} & \multicolumn{2}{|c|}{$\begin{array}{c}P \\
(\%)\end{array}$} & \multicolumn{2}{|c|}{$\begin{array}{c}\text { Uptake of } \\
P \\
\text { (kg/fed) }\end{array}$} & \multicolumn{2}{|c|}{$\begin{array}{c}K \\
(\%)\end{array}$} & \multicolumn{2}{|c|}{$\begin{array}{c}\text { Uptake of } \\
\text { K } \\
\text { (mg/fed) }\end{array}$} \\
\hline & & \multicolumn{2}{|c|}{ Compost } & \multicolumn{2}{|c|}{ Compost } & \multicolumn{2}{|c|}{ Compost } & \multicolumn{2}{|c|}{ Compost } & \multicolumn{2}{|c|}{ Compost } & \multicolumn{2}{|c|}{ Compost } \\
\hline & & With & $\begin{array}{c}\text { With } \\
\text { out }\end{array}$ & With & \begin{tabular}{|c|} 
With \\
out
\end{tabular} & With & \begin{tabular}{|c} 
With \\
out
\end{tabular} & With & $\begin{array}{c}\text { With } \\
\text { out }\end{array}$ & With & \begin{tabular}{|c|} 
With \\
out
\end{tabular} & With & \begin{tabular}{|c} 
With \\
out
\end{tabular} \\
\hline \multicolumn{12}{|c|}{ First season $2017 / 2018$} & & \\
\hline \multirow{3}{*}{$\begin{array}{c}\text { Sakha } \\
93\end{array}$} & S1 & 2.84 & 2.66 & 90.60 & 65.17 & 0.65 & 0.53 & 20.70 & 12.99 & 1.15 & 1.03 & 36.69 & 25.21 \\
\hline & S2 & 2.45 & 2.23 & 66.20 & 48.84 & 0.53 & 0.36 & 14.30 & 7.88 & 1.04 & 0.86 & 28.08 & 18.83 \\
\hline & S3 & 2.03 & 1.56 & 52.60 & 31.20 & 0.47 & 0.28 & 12.20 & 5.60 & 0.85 & $\mid 0.72$ & 22.02 & 14.40 \\
\hline \multirow{3}{*}{ Masr 1} & S1 & 2.71 & 2.47 & 75.90 & 57.06 & 0.50 & 0.46 & 14.00 & 10.63 & 1.12 & 0.98 & 31.36 & 22.64 \\
\hline & S2 & 2.25 & 2.20 & 58.50 & 49.28 & 0.40 & 0.33 & 10.40 & 7.39 & 0.98 & 0.80 & 25.48 & 17.92 \\
\hline & S3 & 1.98 & 1.35 & 45.50 & 25.11 & 0.36 & 0.24 & 8.30 & 4.46 & 0.70 & 0.69 & 16.10 & 12.83 \\
\hline \multicolumn{2}{|c|}{$\begin{array}{l}\text { LSD.0.05 } \\
\text { salinity }\end{array}$} & 0.03 & 0.012 & 5.60 & 3.64 & 0.05 & ns & 1.76 & 2.64 & 0.07 & 0.06 & 3.40 & 2.28 \\
\hline \multicolumn{2}{|c|}{$\begin{array}{l}\text { LSD. } 0.05 \\
\text { compost }\end{array}$} & ns & 0.07 & 2.53 & 1.15 & 0.04 & ns & ns & ns & ns & ns & 2.40 & ns \\
\hline \multicolumn{2}{|c|}{ Interaction } & $* * *$ & $* * *$ & $* * *$ & *** & * & * & * & ** & ** & *** & *** & $* * *$ \\
\hline \multicolumn{14}{|c|}{ Second season 2018/ 2019} \\
\hline \multirow{3}{*}{$\begin{array}{c}\text { Sakha } \\
93\end{array}$} & s1 & 2.95 & 2.74 & 94.11 & 67.13 & 0.68 & 0.59 & 21.69 & 14.46 & 1.24 & 1.08 & 39.56 & 26.46 \\
\hline & S2 & 2.68 & 2.40 & 72.36 & 52.56 & 0.56 & 0.41 & 15.12 & 8.98 & 1.13 & 1.02 & 30.51 & 22.34 \\
\hline & S3 & 2.09 & 1.60 & 54.13 & 32.00 & 0.51 & 0.34 & 13.21 & 6.80 & 0.93 & 0.90 & 24.09 & 18.00 \\
\hline \multirow{3}{*}{ Masr 1} & S1 & 2.78 & 2.60 & 77.84 & 60.06 & 0.55 & 0.49 & 15.40 & 11.32 & 1.16 & 1.05 & 32.48 & 24.26 \\
\hline & S2 & 2.35 & 2.25 & 61.10 & 50.40 & 0.43 & 0.37 & 11.18 & 8.29 & 1.09 & 0.96 & 28.34 & 21.50 \\
\hline & S3 & 2.03 & 1.38 & 46.69 & 25.67 & 0.40 & 0.29 & 9.20 & 5.39 & 0.85 & 0.75 & 19.55 & 13.95 \\
\hline \multicolumn{2}{|c|}{$\begin{array}{l}\text { LSD.0.05 } \\
\text { salinity }\end{array}$} & ns & 0.24 & 5.11 & 6.48 & 0.05 & 0.05 & 3.46 & 2.81 & 0.033 & 0.070 & 5.080 & 2.330 \\
\hline \multicolumn{2}{|c|}{$\begin{array}{l}\text { LSD. } 0.05 \\
\text { compost }\end{array}$} & ns & ns & 1.70 & ns & ns & 0.03 & ns & 0.94 & 0.034 & 0.024 & ns & ns \\
\hline \multicolumn{2}{|c|}{ Interaction } & ns & ** & $* * *$ & $* * *$ & * & $* * *$ & ns & $* * *$ & *** & $* * *$ & * & ** \\
\hline
\end{tabular}

Micronutrients concentration and uptake in grains of wheat varieties.

The effect of compost on micronutrients concentrations $(\mathrm{mg} / \mathrm{kg})$ and uptake $(\mathrm{mg} / \mathrm{fed})$ in grains of wheat varieties under different saline soil levels in two seasons are shown in Table (9). The data indicated that applying compost caused markedly increases in concentrations and uptake of $\mathrm{Fe}, \mathrm{Mn}$ and
$\mathrm{Zn}$ in grains as decreasing soil salinity levels. The effect of saline soil levels on micronutrients i.e. $\mathrm{Fe}, \mathrm{Mn}$ and $\mathrm{Zn}$ concentration and uptake in grains wheat plants were significant increases with decreasing soil salinity in both seasons with compost treatments, except the $\mathrm{Mn}$ concentration was no significant affected in soil untreated with compost in first season. On the other hand, the $\mathrm{Fe}$ concentration and uptake in wheat 
Kh. A. H. Shaban, et al.,

cultivation was significant for soil treated with or without compost in first season. The $M n$ and $\mathrm{Zn}$ concentration in grains wheat varieties were no significant for soil treated with compost, while the Mn and $\mathrm{Zn}$ uptake were significant for soil treated with or without compost in first season.

As well as, the $\mathrm{Fe}$ and $\mathrm{Mn}$ concentration in grains wheat varieties were significant affected with compost, while the $\mathrm{Zn}$ concentration was no significant as affected with or without compost in second season. Also the Fe and $\mathrm{Zn}$ uptake in grains wheat varieties were significant for soil treated with or without compost, while Mn was significant for soil untreated with compost in second season. The interaction between soil salinity levels and wheat varieties on $\mathrm{Fe}, \mathrm{Mn}$ and $\mathrm{Zn}$ concentration and uptake were significant in soil treated with or without compost in both seasons, while the increase of Mn uptake was no significant for soil treated with compost in second season.

Table ( 9 ). Micronutrients concentration and uptake in grains of wheat cultivars.

\begin{tabular}{|c|c|c|c|c|c|c|c|c|c|c|c|c|c|}
\hline \multirow{3}{*}{$\begin{array}{c}\text { Varity of } \\
\text { wheat }\end{array}$} & \multirow{3}{*}{$\begin{array}{c}\text { Levels of } \\
\text { soil } \\
\text { salinity }\end{array}$} & \multirow{2}{*}{\multicolumn{2}{|c|}{$\begin{array}{c}\begin{array}{c}\mathrm{Fe} \\
(\mathrm{mg} / \mathrm{kg})\end{array} \\
\text { Compost }\end{array}$}} & \multirow{2}{*}{\multicolumn{2}{|c|}{$\begin{array}{c}\text { Uptake of } \\
\text { Fe } \\
\text { (g/fed) }\end{array}$}} & \multirow{2}{*}{\multicolumn{2}{|c|}{$\begin{array}{c}\begin{array}{c}M n \\
(\mathrm{mg} / \mathrm{kg})\end{array} \\
\text { Compost }\end{array}$}} & \multirow{2}{*}{\multicolumn{2}{|c|}{$\begin{array}{c}\text { Uptake of } \\
\begin{array}{c}\text { Mn } \\
\text { (g/fed) }\end{array} \\
\text { Compost }\end{array}$}} & \multirow{2}{*}{\multicolumn{2}{|c|}{$\begin{array}{c}\begin{array}{c}\mathrm{Zn} \\
(\mathrm{mg} / \mathrm{kg})\end{array} \\
\text { Compost }\end{array}$}} & \multirow{2}{*}{\multicolumn{2}{|c|}{$\begin{array}{c}\text { Uptake of } \\
\begin{array}{c}\mathrm{Zn} \\
(\mathrm{g} / \mathrm{fed})\end{array} \\
\text { Compost }\end{array}$}} \\
\hline & & & & & & & & & & & & & \\
\hline & & With & $\begin{array}{c}\text { With } \\
\text { out }\end{array}$ & With & $\begin{array}{c}\text { With } \\
\text { out }\end{array}$ & With & $\begin{array}{c}\text { With } \\
\text { out }\end{array}$ & With & $\begin{array}{c}\text { With } \\
\text { out }\end{array}$ & With & $\begin{array}{c}\text { With } \\
\text { out }\end{array}$ & With & $\begin{array}{c}\text { With } \\
\text { out }\end{array}$ \\
\hline \multicolumn{14}{|c|}{ First season $2017 / 2018$} \\
\hline \multirow{3}{*}{$\begin{array}{c}\text { Sakha } \\
93\end{array}$} & S1 & 178.40 & 130.23 & 569.10 & 319.06 & 88.90 & 67.82 & 283.59 & 166.16 & 40.61 & 33.49 & & 82.05 \\
\hline & S2 & 136.00 & 113.75 & 367.20 & 249.11 & 80.34 & 63.84 & 216.92 & 139.81 & 35.61 & 27.31 & 96.15 & 59.81 \\
\hline & S3 & 123.95 & 102.92 & 321.03 & 205.84 & 72.16 & 58.33 & 186.89 & 116.66 & 24.62 & 20.17 & 63.77 & 40.34 \\
\hline \multirow{3}{*}{ Masr 1} & s1 & 173.90 & 122.68 & 486.92 & 283.39 & 78.34 & 62.85 & 219.35 & 145.18 & 37.94 & 27.64 & 106.23 & 63.85 \\
\hline & S2 & 132.20 & 114.00 & 343.92 & 255.36 & 64.58 & 58.35 & 167.91 & 130.70 & 30.66 & 23.88 & 79.72 & 53.49 \\
\hline & S3 & 118.50 & 96.70 & 272.55 & 179.86 & 60.83 & 52.17 & 139.91 & 97.04 & 22.94 & 18.34 & 52.76 & 34.11 \\
\hline \multicolumn{2}{|c|}{ LSD. 0.05 salinity } & 1.13 & 2.36 & 5.74 & 6.31 & 2.43 & ns & 0.65 & 3.46 & 4.08 & 2.27 & 2.36 & 2.33 \\
\hline \multicolumn{2}{|c|}{$\begin{array}{l}\text { LSD. } 0.05 \\
\text { compost }\end{array}$} & 1.05 & 1.69 & 6.00 & 2.57 & ns & 0.81 & 2.21 & 2.05 & ns & 0.99 & 2.21 & 1.74 \\
\hline \multicolumn{2}{|c|}{ Interaction } & & 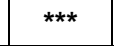 & 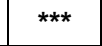 & $\star * *$ & * & $* * *$ & $* * *$ & $* * *$ & & & $* * *$ & *** \\
\hline \multicolumn{14}{|c|}{ Second season 2018/ 2019} \\
\hline \multirow{3}{*}{$\begin{array}{c}\text { Sakha } \\
93\end{array}$} & s1 & 182.44 & 136.10 & 611.17 & 352.50 & 92.57 & 72.31 & 310.11 & 187.28 & 42.19 & 36.74 & 141.34 & 95.16 \\
\hline & S2 & 141.77 & 120.88 & 404.04 & 294.95 & 83.64 & 67.82 & 238.37 & 165.48 & 38.94 & 30.19 & 110.98 & 73.66 \\
\hline & S3 & 135.00 & 108.55 & 367.20 & 233.38 & 77.80 & 62.00 & 211.62 & 133.30 & 29.43 & 24.61 & 80.05 & 52.91 \\
\hline \multirow{3}{*}{ Masr 1} & S1 & 177.30 & 130.47 & 567.36 & 319.65 & 84.93 & 66.51 & 271.78 & 162.95 & 40.61 & 29.74 & 129.95 & 72.86 \\
\hline & S2 & 139.50 & 121.00 & 410.13 & 281.93 & 69.52 & 54.37 & 204.39 & 126.68 & 35.79 & 27.63 & 105.22 & 64.38 \\
\hline & S3 & 123.88 & 110.54 & 328.28 & 215.55 & 54.39 & 50.31 & 144.13 & 98.10 & 27.88 & 25.46 & 73.88 & 49.65 \\
\hline \multicolumn{2}{|c|}{ LSD. 0.05 salinity } & 5.11 & 9.66 & 5.60 & 0.65 & 2.56 & 2.52 & 6.90 & 3.48 & 3.39 & 1.13 & 4.72 & 2.62 \\
\hline \multicolumn{2}{|c|}{$\begin{array}{l}\text { LSD. } 0.05 \\
\text { compost }\end{array}$} & 3.82 & ns & 3.58 & 2.16 & 2.91 & ns & ns & 3.09 & ns & ns & 3.52 & 0.94 \\
\hline \multicolumn{2}{|c|}{ Interaction } & $\pi$ & $* * *$ & $* * *$ & $* * *$ & $\pi x$ & x & ns & $* * *$ & ** & $\star *$ & $* * *$ & ** \\
\hline
\end{tabular}


Response of two levels wheat cultivars to compost application in saline .....

Finally, it could be concluded that the data presented in this work demonstrated the great importance of the appropriate role of compost improving soil characters and enhancing its productivity of wheat as well as promotes the uptake of $\mathrm{Fe}, \mathrm{Mn}$ and $\mathrm{Zn}$ by wheat plants under the conditions of saline soil. These results are seemed to be dependent on soil properties that limit the buffering capacity and native nutrient content. Finally, it is concluded that the concentration and uptake of micronutrients in wheat plants, generally, reflect their available contents in soil and these was a decrease in soil salinity and soil pH under different soil salinity levels combined with compost. These results are in agreement by Wang et al., (2016) who, reported that the compost application was increased the $\mathrm{Fe}, \mathrm{Mn}$ and $\mathrm{Zn}$ concentrations in straw and grain wheat, compared with the control. Rutkowska et al., (2014) suggested that application of compost led to increase for micronutrients i.e. $\mathrm{Fe}, \mathrm{Mn}$ and $\mathrm{Zn}$ concentration in straw or grains of wheat.

\section{Quality of wheat cultivation under} soil salinity levels.

Data in Table (10) showed the effect of saline soil different levels and compost application on quality of wheat varieties i.e. Carbohydrate (\%), proline ( $\mathrm{mg} \mathrm{g}^{-1}$. f.w), protein and chlorophyll ( $\mathrm{mg} \mathrm{g}^{-1}$ f.w.) were positive effect under used compost in both sessions.

Table (10). Wheat quality under saline soil salinity levels with or without compost.

\begin{tabular}{|c|c|c|c|c|c|c|c|c|c|}
\hline \multirow{3}{*}{$\begin{array}{c}\text { Varity of } \\
\text { wheat }\end{array}$} & \multirow{3}{*}{$\begin{array}{c}\text { Levels of } \\
\text { soil } \\
\text { salinity }\end{array}$} & \multirow{2}{*}{\multicolumn{2}{|c|}{$\begin{array}{c}\begin{array}{c}\text { Carbohydrate } \\
(\%)\end{array} \\
\text { Compost } \\
\end{array}$}} & \multirow{2}{*}{\multicolumn{2}{|c|}{$\begin{array}{c}\begin{array}{c}\text { Protein } \\
(\%)\end{array} \\
\text { Compost } \\
\end{array}$}} & \multirow{2}{*}{\multicolumn{2}{|c|}{$\begin{array}{c}\begin{array}{c}\text { Proline } \\
\text { (mg /g f.w.) }\end{array} \\
\text { Compost } \\
\end{array}$}} & \multirow{2}{*}{\multicolumn{2}{|c|}{$\begin{array}{c}\text { Chlorophyll } \\
\text { (mg/g f.w.) } \\
\text { Compost }\end{array}$}} \\
\hline & & & & & & & & & \\
\hline & & With & Without & With & Without & With & Without & With & Without \\
\hline \multicolumn{10}{|c|}{ First season $2017 / 2018$} \\
\hline \multirow{3}{*}{ Sakha 93} & s1 & 72.95 & 67.55 & 16.33 & 15.30 & 15.82 & 21.59 & 38.50 & 34.85 \\
\hline & $\mathbf{S 2}$ & 69.30 & 62.96 & 14.09 & 12.82 & 27.95 & 35.47 & 36.83 & 32.50 \\
\hline & S3 & 64.20 & 60.22 & 11.67 & 8.97 & 31.85 & 41.25 & 35.77 & 25.10 \\
\hline \multirow{3}{*}{ Masr 1} & S1 & 75.30 & 69.75 & 15.58 & 14.20 & 17.52 & 24.60 & 36.99 & 30.67 \\
\hline & S2 & 71.10 & 65.33 & 12.94 & 12.65 & 31.42 & 38.74 & 34.85 & 28.65 \\
\hline & S3 & 67.00 & 61.85 & 11.39 & 7.76 & 36.25 & 43.16 & 30.60 & 22.15 \\
\hline \multicolumn{2}{|c|}{ LSD.0.05 salinity } & ns & ns & 1.73 & 1.13 & 3.00 & 0.65 & 2.85 & 2.99 \\
\hline \multicolumn{2}{|c|}{ LSD. 0.05 compost } & ns & ns & ns & ns & ns & ns & ns & 1.05 \\
\hline \multicolumn{2}{|c|}{ Interaction } & *** & ns & ns & ns & $* * *$ & $* \star *$ & ns & *** \\
\hline \multicolumn{10}{|c|}{ Second season 2018/ 2019} \\
\hline \multirow{3}{*}{ Sakha 93} & s1 & 76.99 & 70.48 & 16.96 & 15.76 & 12.84 & 19.34 & 40.22 & 36.90 \\
\hline & S2 & 72.80 & 65.30 & 15.41 & 13.80 & 22.67 & 33.41 & 37.58 & 33.88 \\
\hline & S3 & 69.50 & 62.11 & 12.02 & 9.20 & 28.17 & 37.85 & 34.88 & 29.45 \\
\hline \multirow{3}{*}{ Masr 1} & s1 & 78.30 & 73.98 & 15.99 & 14.95 & 16.55 & 20.16 & 38.40 & 35.90 \\
\hline & S2 & 74.20 & 71.63 & 13.51 & 12.94 & 24.32 & 34.13 & 35.54 & 31.29 \\
\hline & S3 & 70.56 & 70.22 & 11.67 & 7.94 & 30.85 & 40.22 & 32.44 & 26.47 \\
\hline \multicolumn{2}{|c|}{ LSD.0.05 salinity } & ns & ns & 1.73 & 2.85 & 3.27 & 1.31 & 2.64 & 4.08 \\
\hline \multicolumn{2}{|c|}{ LSD. 0.05 compost } & ns & ns & ns & ns & 1.05 & ns & ns & ns \\
\hline \multicolumn{2}{|c|}{ Interaction } & * & *** & ns & ** & *** & *** & * & *** \\
\hline
\end{tabular}


The carbohydrate (\%) reduced by high soil salinity levels for soil untreated with compost compared with soil treated compost in both seasons. Carbohydrate (\%) content in wheat sakha 93 varieties was higher than wheat Masr1 variety in both seasons. The effect of soil salinity levels and wheat varieties as treated or untreated with compost on carbohydrate (\%) content in tow wheat cultivation were no significant, while the interaction between soil salinity levels and variety of carbohydrate content in wheat plants were significant increases with decreasing soil salinity levels as affected with compost in first season, while significant in second seasons for soil treated or untreated with compost. These results are in agreement by $\mathrm{El}-Q u e s n i$ et al (2010) found that the total carbohydrate concentration (\%) decreased by increasing salinity level caused a depression of photosynthetic actives resulting in $\mathrm{CO}_{2}$ fixation. Mazhar et al (2011) suggested that the effect of compost application on total carbohydrate percentage, it is clear in the two growing seasons, were increased by using compost application under saline stress. This may be attributed to the effect of compost as a source of essential nutrients besides improving the physical and chemical properties of the soil.

Regarded data in Table (10) illustrated that the effect of soil salinity levels on protein (\%) content in grains wheat cultivars with or without compost were significant increases with decreasing soil salinity levels in both seasons, while the protein content in grain wheat cultivars was no significant with or without compost in both seasons. The interaction between soil salinity and compost on protein $(\%)$ were significant decreased with increasing soil salinity without compost in second season. Increase of total protein (\%) in both wheat varieties could be attributed to the role of organic matter amendments in improving plant growth through higher uptake of water and nutrients from soil which decreased the negative effects of salt and nutrient thereby enhancing plant yield. The increase of soil salinity levels led to reduced level of protein in the physiologically active grains is due to reduced capacity to incorporate amino acids into proteins and an increase in proteolytic enzymes or due to contribution of polysomes to monosomes under salinity stress condition or due to synthesis of absiccic acid increases the activity of RNase, thus indirectly inhibiting the protein synthesis. These results are in agreement by Datta et al (2009) found that the increases of protein (\%) content in wheat varieties with decreasing salt stress. Tayebeh et al (2010) reported that the compost application lead to grain protein content enhancement due to its effect on soil structure and consequently increase in plant nutrients uptake with no negative effect on seed protein pattern.

Concerning, the proline may play a protective role against the osmotic potential generated by salt. Compost application led to decreased proline concentration compared with untreated plants. The effect of different soil salinity levels on proline (mg/g f.w.) was significant increases with increasing soil salinity levels with or without compost in both seasons, while the effect of wheat varieties was no significant in first season and significant of soil treated with compost in second season. The interaction effects compost and different levels of soil salinity were significant decreased in proline concentration, thus could be due to the influence of compost on decreasing the hazard effect created by salinity treatment. Proline concentration increased under salinity 
stress to make plants more adapted to these unsuitable conditions. Proline is considered as a cell stabilizer for osmotic potential and some enzymes synthesis. The increasing of concentration of proline in wheat plants was due to the existence of halotolerent bacteria that can accumulate or synthesize organic compatible solutes, such as glutamine, proline and glycine betaine, that showed a positive effect on plant growth, Kobra et al (2013). ElQuesni et al (2010) indicated that the salt stress increased the proline content in leaves tissues with a gradual increase in its percentage.

On the other hand the total chlorophyll (mg/g f.w.) in Table (10) showed that the effect of soil salinity levels was significant increases total chlorophyll (mg/g f.w.) content in wheat varieties with decreasing soil salinity level in both seasons as affected with or without compost, while the chlorophyll (mg/g f.w.) content in wheat cultivations was significant decreased in soil untreated compost in first season and no significant in soil with or without compost in second season. the interaction between soil salinity levels and wheat varieties on chlorophyll chlorophyll (mg/g f.w.) were significant in soil untreated with compost in first season, while, significant in second season for soil treated with or without compost. These results are in agreement by El-Quesni et al (2010) reported that the total carbohydrate (\%) decreases by increasing salinity level caused a depression of photosynthetic activities resulting in $\mathrm{CO}_{2}$ fixation compared with control plants.

Generally, the wheat quality (prolien, protein, chlorophyll and carbohydrate) were increase contents in wheat Sakha 93 than Masr1 under soil salinity as affected with compost and without.

\section{Conclusion}

It could be concluded that the application of compost is useful the higher wheat Sakha 93 than Masr1 varieties crop production and quality of the produce also improves saline soil properties.

\section{REFERENCES}

Abbas, G., M. Saqib, Q. Rafique, M. Rahman, J. Akhtar, M. A. Haq and M. Nasim (2013). Effect of salinity on grain yield and grain quality of wheat (Triticum aestivum L.). Pak. J. Agri. Sci. 50 (2): 185- 189.

Abd EladI, M., N.H. Abou Baker and S. Ashry (2010). Impact of compost and mineral fertilization and irrigation regime on wheat and sequenced maize plants. Minufiya J Agric. Res., 35: 2245-2262.

Abo- Soliman, M.S.M., M.M. Saied, H. A. Shams El-Din and M.A. Abo-El-Soud (2001). Effect of marginal water on soil physical and chemical properties. Zagazig. J. Agric. Res.28 (6): 230-245.

Babbu, S.B., S. Jagdeep, S. Gurbir and K. Gurpreet (2015). Effect of long term application of inorganic and organic fertilizers on soil organic carbon and physical properties in maize - wheat rotation. Agronomy J. 5: 220- 238.

Bates, L.S., R.P. Waldren and I.D. Teare (1973). Rapid determination of free proline under water stress studies. Plant and Soil, 39: 205-207.

Brunner, P.H. and H.R. Wasmer (1978). Methods of Analysis of Sewage Sludge Solid Wastes and Compost. W.H.O. International Reference Center for Wastes Disposal ( $\mathrm{H}-8600)$, Dulendrof Switzerland.

Chitravadivu, C., V. Bal Krishnan, J. Manikandan, T. Elavazhagan and $\mathrm{S}$. Jayakumar (2009). Application of food waste compost on soil microbial population in groundnut cultivated 
Kh. A. H. Shaban, et al.,

soil . India. Middle - East J. Sci. Res., 4: 90-93.

Cottenie, A., M. Verloo, L. Kiekens, G. Velghe and R. Cameriynck (1982). Chemical Analysis of Plant and Soil. Laboratory of Analytical and Agrochemistry, State Univ., Ghent , Belgium.

Datta, J. K., S. Nag, A. Banerjee and N. K. Mondal (2009). Impact of salt stress on five varieties of wheat (Triticum aestivum L.) cultivars under laboratory condition. J. Appl. Sci. Manage., 13 (3): 93- 97.

Dubios, M., K.A. Gilles, J.K. Hamilton, P.A. Robers and P.A. Smith (1956). A colorimetric for determination of sugar and related substances. Anal., Chin., 28: 350.

El-Hamahmy, A.F., Kh. M. Ghanem, O.N. Massoud, E.A. Hassn and A. M. O. Shoeip (2014). Improving the productivity of wheat (Triticum aesitivum L) cultivated under saline soil using some N2-fixers halophilic bacteria and compost. Middle East $\mathrm{J}$. of Agric. Res., 3 (4): 827- 837.

El-Maaz, E.I.M., H.M.R. Ahmed and Kh. A. Shaban (2014). Soil chemical properties and wheat productivity as affected by organic, bio-fertilization and cultivation methods in saline soil. Minufiya J. Agric. Res., 39 (6): 1955- 1968.

EI-Quesni, F.E.M., S. M. Zaghloul and H. S. Siam (2010). Effect of microbien and compost on growth and chemical composition of Schefflera arboricola L. under salt stress. J. of American Sci. 6 (10): 1073- 1080.

El-Shinnawi, M.M., F. S. El-Shafie, M.R. Abd El- Hady and M.N. F. Riham (2009). Effect of mineral phosphate and organic fertilizers on plant growth and nutrition contents of faba-bean grown on different soils. Minufiya J. Agric. Res., 34(4): 1737-1757

FAO (1995). Improvement and Production, Drainage and Salinity. An international Source Book.Paris.
Hammad, S. A. R., Kh. A. H. Shaban and M. F. Tantawy (2010). Studies on salinity tolerance of two peanut cultivars in relation to growth, leaf water content. Some chemical Aspects and yield. J. of Applied Sci. Res., 6 (10): 1517- 1526.

Ghumlam, A., S. Muhammad, R. Qaisir, M.A. Rahman, A. Javaid, M. U. Anwar and M. Nasim (2013). Effect of salinity on grain yield and grain quality of wheat (Triticum aestivum L.). Pak. J. Sci., 50 (2): 185- 189.

Kandil, A. A., A. E. Sharief and M. A. ElOkda (2012). Germination and seedling characters of different wheat cultivars under salinity stress. $J$ of Basic and Applied Sci., 8 : 585 - 596.

Klute, A. (1986). Methods of Analysis. Part 1, Soil Physical Properties", ASA and SSSA, Madison, WI.

Kobra, S., A. Jafar, A. Ahmed and B. Shiva (2013). The effect of microbial inoculations on physiology response of two wheat cultivars under salt stress. International Journal of Advanced Biological and Biomedical Research ISSN : 2322 - 4827 - 1(4): 421 - 431.

Koyro, H.W. (2006). Effect of salinity on growth, photosynthesis, water relations and solute composition of the potential cash crop halophyte Plant ago coronopus (L-). J. Environ. Exp. Bot.; 56: 136-146.

Lantican, M. A., H. J. Dubin, M. L. Morris, R. M. Trethowan, D. Hodson, H. J. Braun, W. H. Pfeiffer and M. Van Ginkel (2005). Impact of International Wheat Breeding Research in the in the Developing World, 1988- 2002. Wheat Breeding Environments. Mexico, D.F.; International Maize and Wheat Improvement Center (CIMMYT).

Mariangela, D. and M. Francesco (2015). Effectiveness of organic wastes as fertilizers and amendments in salt affected soils. Agric. J. 5 : 221- 230. 
Mazhar, A. A. M., N. G. Abdel-Aziz, S. I. Shedeed and S. M. Zaghloul (2011). Effect of Nile compost application on growth and chemical constituents of Jaropha curcas grown under different salinity levels of diluted sea water. Austr. J. of Basic and Applied Sci. 5 (9): 967- 974.

Munns, R. and M. Gilliham (2015). Salinity tolerance of crops what is the cost. The New Phytologist, 208 : 668 - 673.

Muzafar, I., S. Irshad, M. Nadeem, F. Tatheer and B. I. Arfa (2018). Salinity effects on wheat (Triticum aestivum L.) characteristics A Review Article. Intr . J. .of Agron. and Agric. Res., 12 (3): 1- 15.

Nasef, M. A., Kh. A. Shaban and A. F. Abd El-Hamide (2009). Effect of compost, compost tea and bio-fertilizer application on some chemical soil properties and rice productivity under saline soil condition. J. Agric. Mansoura Univ. 34 (4): 2609- 2623.

Niaz, A.K., R. Inaytullah, A. K. Shahmir, A. Amjad, R. Sajjad, A. Muneer, A. K. Fahad, R. Muhammad and W. Fazli (2016). Effect of salts stress on the growth and yield of wheat (Triticum aestivum L.). American J. of plant Sci. $7: 2257$ - 2271.

Page, A.L., R.H. Miller and D.R. Keeney (1982). "Methods of Chemical Analysis". Part 2: Chemical and Microbiological Properties (Second Edition). American Society of Agronomy, Inc. and Sci. Soc. of America, Inc. Publishers, Madison, Wisconsin U.S.A.

Rasool, R., S.S. Kukal and G.S. Hira (2007). Soil physical fertility and crop performance as affected by long term application of FYM and inorganic fertilizers in rice-wheat system. Soil Till. Res., 96 : 64-72

Russell, D. F. (1994). MSTAT-C v.2.1 (computer based data analysis software). Crop and Soil Sci. Department, Michigan State University, USA.
Rutkowska, B., W. Szulc, T. Sosulski and W. Stepien (2014). Soil micronutrient availability to crops affected by long term inorganic and organic fertilizer applications. Plant Soil and Environment. . 60: 198-203.

Ryan, J., S. Garabet, K. Harmsen and A. Rashid (1996). A Soil and Plant Analysis. "Manual Adapted for the West Asia and North Africa Region", 140p. ICARDA, Aleppo, Syria.

Seddik, W. M. A., H. A. Zein El-Abdeen and W. Z. Hassan (2016). Effectiveness of soil amendments application on sandy soil properties and peanut productivity. Egypt J. Soil Sci., 56 (3): 519 - 535.

Soheil, R., M. Hossien, S. Gholamreza, H. Leila, J. Mozhden and E. Hassan (2012). Effect of compost municipal waste and its leachate on some soil chemical properties and corn plant responses. Inter. J. Agric. Res. And Revi. 2 (6): 801 - 814.

Soltanpour, N. (1985). Use of ammonium bicarbonate-DTPA soil test to evaluate elemental availability and toxicity. Soil Sci. Plant Anal. 16 (3): 323 - 338.

Tandon, H. L. S. (2000). Fertilizer Organic Manures Wastes and Bio-fertilizers Components of Integrated Plant. Fertilizer Development and consultation organization 204- 204, A Bhanot Corner, 1-2 Pamposh Enclave New Delhi. 110048. India.

Tayebed, A., A. Abass and A.K. Seyed (2010). Effect of organic and inorganic fertilizers on grain yield and protein banding pattero of wheat. Austr. J. of Crop Sci. 4 (6): 384- 389.

Wang, F., Z. Wang, C. Kou, Z. Ma and D. Zhao (2016). Responses of wheat yield, macro and micronutrients and heavy metals in soil and wheat following the application of manure compost on the North Chine Plain. J. Pone, 1 (1): 1:18

Witham, F.H., D.F. Blaydes and P.M. Devin (1971). Experiments in plant physiology. Van Nosland Reihold. Co. New York, 55-58. 
Kh. A. H. Shaban, et al.,

\section{استجابة صنفان من القـح لاضافات الكمبوست فى الأراضى الملحية}

خالد عبده حسن شعبان، غادة عبد العزيز عبدالقادر، سهام محمود عبدالعظيم

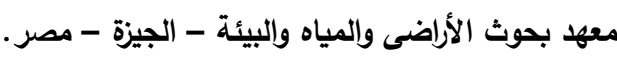

الملخص العربى

اجريت تجربتان حقليتان في قرية الرواد في سهل الحسينية ، الثرقية ، محافظة الثرقية لمدة موسمين شتاء متتاليين

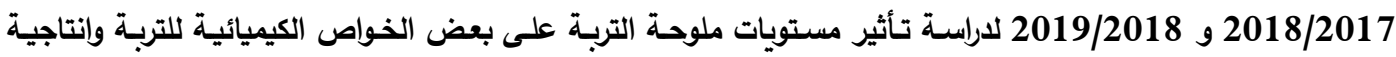

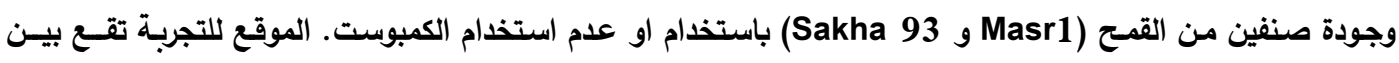

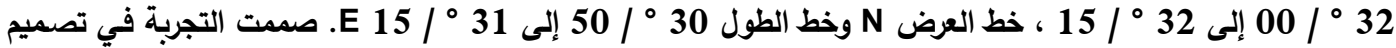

قطاعات منثقة مرة واحده split plot فى أربعة مكررات.

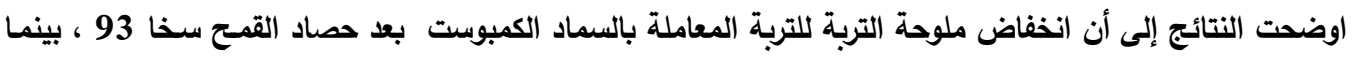

زاد انخفاض التربة للتربة بعد حصاد القمح Masr1 على التوالي مقارنة مع ملوحة التربة الأولية. من ناحية أخرى ، كانت

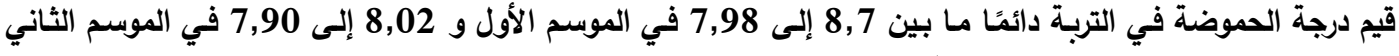

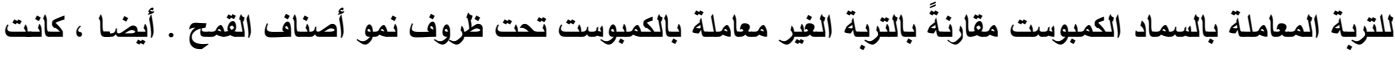

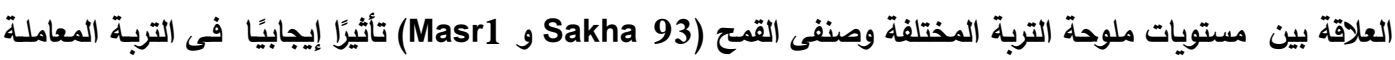

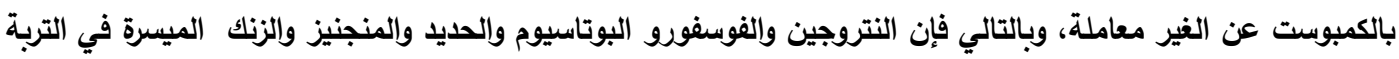
كانت يتزداد مع انخفاض ملوحة التربة في كلا الموسمين.

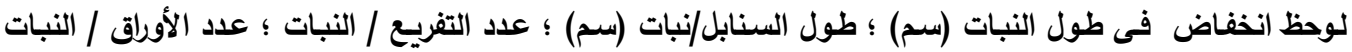

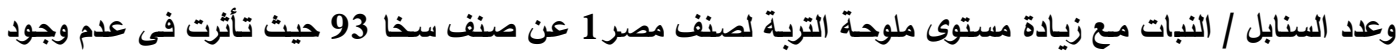

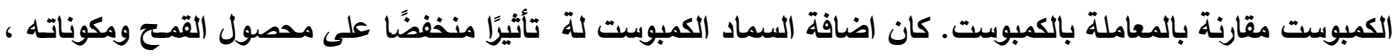

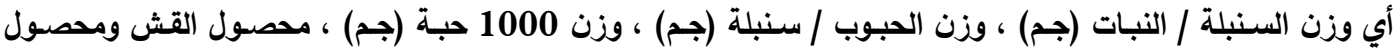

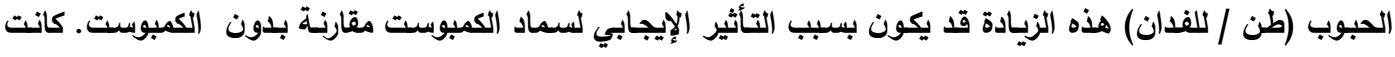

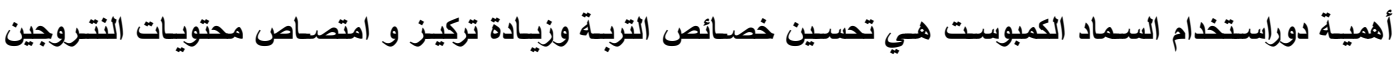

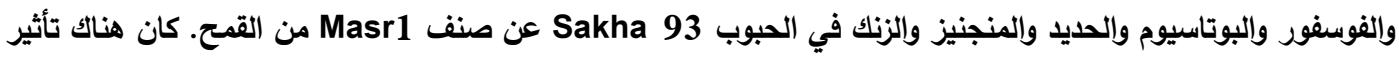

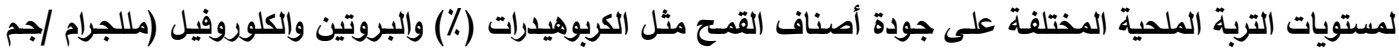
وزن رطب) كانت زيادة هذه الصفات لصنف 93 عن صنف مصر 1 تحت استخدام الكمبوست فسى كلا الموسمين بينما البرولين (مليجرام/جم وزن رطب) ، زاد محتوى نباتات القمح مـع زيـادة مستوى ملوحة التربـة خاصـة التربة الغير معاملـة

بالكمبوست.

التوصية : وجد ان استخدام الكمبوست ادى الى تحسن صفات التربة وانتاجية وجودة صنف القـح سخا 93 عن صنف مصر 1 تحت ظروف مستويات الملوجة للتربة .

أسماء السادة المحكمين

مركز البحوث الزراعية - الجيزة

أ.د/ الحسينى عبدالغفار أبو حسين كلية الززاعة - جامعة المنوفية البراعة 
Response of two levels wheat cultivars to compost application in saline..... 